\title{
The Bird Assemblage of the Darwin Region (Australia): Twenty Years, No Change ${ }^{+}$
}

\author{
Sarah Fischer ${ }^{1, *}$, Andrew C. Edwards ${ }^{1}$, Patice Weber ${ }^{1}$, Stephen T. Garnett ${ }^{2}$ and Timothy G. Whiteside ${ }^{3}$ \\ 1 College of Engineering, IT \& Environment, Research Institute for the Environment and Livelihoods, Charles \\ Darwin University, Darwin, NT 0909, Australia; andrew.edwards@cdu.edu.au (A.C.E.); \\ patrice.weber@cdu.edu.au (P.W.) \\ 2 College of Engineering, IT \& Environment, EIE Environment, Charles Darwin University, Darwin, NT 0909, \\ Australia; stephen.garnett@cdu.edu.au \\ 3 Environmental Research Institute of the Supervising Scientist, Darwin, NT 0820, Australia; tim.white- \\ side@environment.gov.au \\ * Correspondence: sarah.fischer@cdu.edu.au \\ † Presented at the 1st International Electronic Conference on Biological Diversity, Ecology and Evolution, 15- \\ 31 March 2021; Available online: https://bdee2021.sciforum.net/.
}

Citation: Fischer, S.; Edwards, A.C.; Weber, P.; Garnett, S.T.; Whiteside, T.G. The Bird Assemblage of the Darwin Region (Australia): Twenty Years, No Change. Proceedings 2021 68, x. https://doi.org/10.3390/xxxxx

Published: date

Publisher's Note: MDPI stays neutral with regard to jurisdictional claims in published maps and institutional affiliations.

Copyright: (c) 2021 by the authors. Submitted for possible open access publication under the terms and conditions of the Creative Commons Attribution (CC BY) license (http://creativecommons.org/licenses/by/4.0/)

\begin{abstract}
There has been considerable urban development in the Darwin region over the last twenty years; as for most fauna in Australia since colonisation, the potential effects to the bird assemblage were expected to be disastrous. To provide a broad overview of changes, bird survey data from 1998 and 2018 were extracted from the Birds Australia 'New Atlas of Australian Birds' database. A total of 164 species were categorised into primary food source feeding guilds and levels of food specialisation. This was integrated into ArcGIS along with land use change mapping from 1998 and 2018 to investigate its impact on bird assemblages. There was no significant change in overall species numbers when all sites were analysed. However, when sites were separated into those with increased urbanisation or decreased greenspace, several sites showed a significant change in the number of species. For the majority of species, analysis of primary food types found no difference in the proportion of species within the assemblages between 1998 and 2018, regardless of the level of urbanisation or greenspace; the exception being those species that primarily feed on insects where the difference was just significant. An analysis using bird community data sorted into levels of food specialisation also found no difference between 1998 and 2018 despite habitat changes. These findings suggest that although there has been considerable urban development in the Darwin region, bird communities are remaining relatively stable.
\end{abstract}

Keywords: urban birds; bird assemblages; urbanisation; landscape ecology; land-use change; Geographic Object-Based Image Analysis(GEOBIA); Australian monsoonal tropics

\section{Introduction}

Global population trends show that humans are moving from rural areas into cities at a considerable rate and once sparsely populated regions are being transformed to cope with the influx of people [1,2]. Subsequently, urbanisation is now widely considered a major threat to biodiversity conservation [3-5]. Whilst studies of bird populations in urban areas abound in the temperate zones of both the Northern and Southern hemispheres, research into tropical urban avian communities is scant [6]. This trend is continued in Australian studies with the majority of research being undertaken in the temperate regions, predominantly in the two heavily populated states of New South Wales and Victoria. In contrast, this study is situated in the monsoonal tropics of northern Australia; specifically in Darwin, the capital of the Northern Territory (NT). There has been targeted research on a range of species and thorough overviews of bird distributions within the region [7-9], with more detailed studies of shorebirds [10-13] and mangrove assemblages 
[14-16]. To date, however, there have been no studies of trends in terrestrial bird assemblages as the city has grown. Given the increased rate of urbanisation in the global tropics [17], coupled with high levels of biodiversity [6,18], there is an increasing need to gather data to better understand how bird communities are coping with the rising encroachment of human habitation. One of the most common effects of urbanisation is the increasing prevalence of exotic species [19-21]. Interestingly this has not occurred in the Darwin region with only four species listed as 'foreign invaders', none of which have established permanent breeding populations [22]; it would appear that all the adaptation is being undertaken by native species as their environment is changed. In this paper we shall test this theory.

\section{Experiments}

\subsection{Study Area}

Darwin $\left(12.4634^{\circ} \mathrm{S}, 130.8456^{\circ} \mathrm{E}\right)$ is situated on the north coast of Australia, a landscape dominated by tropical savanna. The population of approximately 140,000 [23] is an increase of nearly 60,000 people in twenty years [24]. The climate is monsoonal and experiences distinct annual dry (May to September) and wet (November to April) seasons with transitional periods between. Mean annual rainfall is approximately $1700 \mathrm{~mm}$; the mean minimum and maximum temperatures range from $19.3^{\circ}$ to $25.3^{\circ}$ and $30.6^{\circ}$ to $33.3^{\circ}$, respectively [25]. Compared to other major Australian capital cities, housing density is low; under 20 private dwellings per square kilometre as opposed to between 150 to 200 per square kilometre in Sydney and Melbourne [26]. A combination of urban and peri-urban environments in the Darwin region provides resources for avian populations elsewhere not available in the dry season.

\subsection{Bird Survey Data}

Survey data were extracted from Birds Australia 'New Atlas of Australian Birds' database (hereafter referred to as the 'Bird Atlas') for the years 1998 and 2018. As the focus of the project was on terrestrial, predominantly diurnal species, Bird Atlas records were excluded if the species was almost exclusively nocturnal, was a waterbird or seabird (except Magpie Geese, Anseranas semipalmata), or the species was considered 'vagrant'. Using information from BirdLife Australia [27], The Atlas of Living Australia [28]and Australian Bird Data Version 1.0 [29], the feeding preferences of species were categorised from most preferred to occasional. To give a general overview of any assemblage changes, the records of 1998 and 2018 were categorized into primary food sources of: fruit, insects, invertebrates, nectar, omnivore, raptor, scavenger, seed, vegetation or vertebrate. If a species was considered to feed on two types of food source equally, both were considered the primary food source. Species were sorted by their level of specialisation; whether they had one, two, three or more food sources.

\subsection{Spatial Data}

To investigate broad-scale changes in urbanisation, Landsat satellite imagery of the study area from April 1998 and 2018 were obtained from the United States Geological Survey scientific agency Global Visualization Viewer (GloVis) with 1998 imagery obtained from the Landsat 4-5 Thematic Mapper (TM) satellite and 2018 imagery taken by the Land sat 8-9 Operational Land Imager (OLI) and Thermal Infrared Sensor (TIRS). April marks the end of the wet season in Darwin, allowing for images with minimal cloud cover and maximum vegetation growth. Images were clipped in ArcGIS version 10.4.1 [30] to a shapefile of Darwin region localities provided by the Northern Territory Government Department of Environment and Natural Resources and then imported into SAGA GIS version 7.3.0 [31]. Classification of land use types was carried out via Geographic ObjectBased Image Analysis (GEOBIA). After automated segmentation in SAGA GIS, the two clipped images were classified by assigning 'training sites' (essentially selecting a 
minimum number of polygons and ascribing them a land use type) and then running a supervised classification. The resulting vector layers were then manually edited using the original satellite image to reassign any misclassified polygons. The initial un-corrected GEOBIA and user-corrected images were then re-imported back into ArcGIS where fifty accuracy assessment points were randomly generated and an error matrix constructed to assess both the producer (SAGA) and user (human) accuracy when assigning classification. For all map classifications satellite imagery, aerial photographs and Google Earth Pro version 7.3.2.5776 (64-bit) were used to assist in the accuracy assessment; however, due to the retrospective nature of the earlier imagery, only the 2018 images could be further checked, if required, using ground control points.

\subsection{Integration of Data}

Following Hahs and McDonnell [32] and Conole and Kirkpatrick [21], the final edited spatial images were re-imported into ArcGIS and a $1 \times 1 \mathrm{~km}$ grid overlaid. The modified Bird Atlas data from 1998 and 2018 were then added as point layer files. As with Conole and Kirkpatrick [21], the locations were taken from the coordinates provided. The grid cells that contained records from both 1998 and 2018 were extracted for each year and the level of land use type in each grid cell calculated. Land use types were combined and simplified into: greenspace (woodland, grass and forest), coastal (mangrove, sea and sand), urbanisation (suburban, periurban, building and road), water and bare earth. Percentage change of greenspace and urbanisation between 1998 and 2018 was calculated for relevant grid cells.

\subsection{Statistical Analysis}

Data were analysed using R version 3.6.1 [33].

Analysis of variance (ANOVA) was used to investigate whether the site and year had an effect on overall species numbers; paired t-tests were then used to examine the significane of any changes between 1998 and 2018 in those sites where urbanisation had increased or greenspace had decreased. The analysis was repeated to assess species primary food source categories.

Finally, effects of land change on feeding specialisation numbers in bird assemblages was also explored. To do this, assemblage species proportions of one, two, three or more food sources were analysed for grid cells that were determined to have had: an increase in urbanisation; a decrease in urbanisation; no change in the amount of urbanisation; an increase in greenspace; a decrease in greenspace.

\section{Results}

\subsection{Spatial Data}

For the 1998 imagery, overall accuracy of the land use classification was 75\% (producer accuracy $72 \%$; user accuracy $84 \%$ ). The 2018 classifcation returned an overall accuracy of $87 \%$ ( $84 \%$ producer and $90 \%$ user accuracies). This difference in accuracy was expected due to the quality differences in the Landsat 5 versus Landsat 8 imagery.

\subsection{Bird Atlas Data}

Overall, there were 23 grid cells that contained Bird Atlas records from both 1998 and 2018. Of these, 9 showed an increase in urbanisation ranging from 0.9 to $58.2 \% ; 8$ indicated a decrease in urbanisation and 6 were recorded as no change. A decrease in greenspace was found in 15 grid cells and 8 were determined to have had an increase. No species considered primarily a scavenger was found in the 23 grid cells.

\subsection{Overall Change in Species Numbers}

164 individual species were represented in the bird records used. Of these, 23 species were recorded in 1998 only and 18 in 2018 only. All sites showed a change in species 
numbers between 1998 and 2018; however, when all sites were included, there was no significant change in total species numbers $(\mathrm{F}=1.1909, p=0.3999$ and $\mathrm{F}=1.9395, p=0.1707$ respectively).

Focussing on those sites where urbanisation had increased or greenspace had decreased over the 20-year period, changes in species numbers was more distinctive. Where urbanisation had increased, five of the nine sites showed an increase in overall species numbers with four of these increases found to be statistically significant $(p<0.05)$. At sites where species numbers decreased two were significant.

In sites where there was a decrease in greenspace, the majority (ten from fifteen) displayed an increase in species numbers but of these only three were found to be significant. The remaining five sites where a decrease in species was recorded three were statistically significant.

\subsection{Changes to Species Numbers with Regards to Primary Food Sources}

Analysis of sites where urbanisation had increased found that there was no significant change in species number by primary food source overall. However, those sites where greenspace was determined to have decreased found a significant change in those species whose primary food source were insects $(p<0.05)$. Some change, too, was noted for raptors but this was not quite statistically significant $(p=0.06)$.

\subsection{Changes to Bird Assemblages with Regards to Primary Food Sources}

Alongside changes to the number of species within bird communities over time, it was also pertinent to investigate whether the proportion of feeding guild types were altered within assemblages due to changing habitats, specifically in those sites where urbanisation has increased or greenspace decreased.

Subsequent analysis showed an increase in urbanisation resulted in no significant difference in the proportion of species of different primary food sources between 1998 and 2018. However, in grid cells that had a decreased amount of greenspace, a slight significant difference was shown in those species that chiefly feed on insects and there is a suggestion of change in those species that primarily feed on fruit, although this was not found to be significant.

\subsection{Levels of Specialisation}

The levels of feeding specialisation within bird communities between 1998 and 2018 showed no significant change despite varying levels of urbanisation and greenspace.

\section{Discussion}

Of the 258 bird species recorded in the Darwin area (escaped, introduced or vagrants excluded), approximately $40 \%$ are considered resident [34] with the remaining species described as mobile. It has previously been thought that mobile species cope better with urbanisation than sedentary species [35,36], although other studies have suggested that highly mobile species may be more vulnerable to habitat changes due to their dependence on larger habitat patches and generally far-reaching home ranges [37-39]. Furthermore, there is also evidence to suggest that the fragmentation of habitats caused by urbanisation is going some way to changing the status of some birds from 'visitor' to 'resident' [40-42].

That there is a significant difference, albeit slight, in the proportion of those species that primarily feed on insects in areas where greenspace has decreased may possibly be attributed to the establishment of urban gardens. Although the size of the greenspace has decreased overall in these locations, in $73 \%$ of the grid cells analysed the proportion of species that preferred insects increased; in contrast, only $47 \%$ of grid cells contained an increase in fructivores. It may be that the plants in these gardens attract a larger array of insects and thus providing more appealing spaces for insectivores. Numerous studies have indicated that those bird species that tend to thrive in urban environments are those 
that nest in cavities or canopies (sites less likely to be disturbed by human activity) and are more likely to be granivorous or omnivorous whereas those species that avoid urban areas are those that predominantly nest in shrubs or trees or at ground level, and have a more specialised diet, frequently insectivores (see [20,21,43], among others). However, these characteristics have been determined from research undertaken in either the Northern Hemisphere or the temperate zones of the Southern Hemisphere, places where garden vegetation is often vastly different to the original habitat. Suburban gardens of the Darwin region often contain native plant species alongside exotics and this mixture may be enough to maintain, or even increase, insect numbers.

That there is no significant difference in the levels of feeding specialisation in bird assemblages is something of a surprise as it would be fair to assume that more generalised species would be increasing and those species with one preferred food source would be forced out, particularly in areas of urban increase. Homogenisation of habitat is an oftquoted result of urbanisation (see [5,44,45] among others) but from this broad overview, it appears not to be affecting the composition of bird communities in the Darwin region. Further research into the characteristics of species making up urban assemblages will go some way to better understanding why this may be.

\section{Conclusions}

Whilst very transient, the population of Darwin and its surrounds has grown significantly between the years 1998 and 2018, and urbanisation has expanded more than $50 \mathrm{~km}$ from the city centre. Despite this avian communities appear to be stable.

Author Contributions: S.F. conceived, designed and performed the experiments; S.F. analysed the data. S.F. and A.C.E. wrote the paper. P.W., S.T.G. and T.G.W. provided guidance and comments on the manuscript. All authors have read and agreed to the published version of the manuscript.

\section{Institutional Review Board Statement:}

\section{Informed Consent Statement:}

Data Availability Statement:

Acknowledgments: This study is part of a larger $\mathrm{PhD}$ project that is supported by Charles Darwin University and the Australian Government via the Research Training Program scholarship.

Conflicts of Interest: The authors declare no conflict of interest.

\section{References}

1. Zhang, X.Q. The trends, promises and challenges of urbanisation in the world. Habitat Int. 2016, 54, $241-252$.

2. United Nations Population Fund. World Population Trends. Availabe online: https://www.unfpa.org/world-population-trends (accessed on).

3. Sewell, S.R.; Catterall, C.P. Bushland modification and styles of urban development: Their effects on birds in south-east Queensland. Wildl. Res. 1998, 25, 41-63, doi:10.1071/WR96078.

4. Cleary, G.P.; Parsons, H.; Davis, A.; Coleman, B.R.; Jones, D.N.; Miller, K.K.; Weston, M.A. Avian Assemblages at Bird Baths: A Comparison of Urban and Rural Bird Baths in Australia. PLoS ONE 2016, 11, e0150899, doi:10.1371/journal.pone.0150899.

5. Bellocq, M.; Leveau, L.; Filloy, J. Urbanization and bird communities: Spatial and temporal patterns emerging from southern South America. In Ecology and Conservation of Birds in Urban Environments, Springer: Berlin/Heidelberg, Germany, 2017; pp. 3554.

6. Wolff, P.J.; DeGregorio, B.A.; Rodriguez-Cruz, V.; Mulero-Oliveras, E.; Sperry, J.H. Bird Community Assemblage and Distribution in a Tropical, Urban Ecosystem of Puerto Rico. Trop. Conserv. Sci. 2018, 11, 1-10, doi:10.1177/1940082918754777.

7. Noske, R.A. The status and ecology of the white-throated grasswren Amytornis woodwardi. EMU 1992, 92, 39-51.

8. Noske, R.A. Breeding biology, demography and success of the rufous-banded honeyeater, Conopophila albogularis, in Darwin, a monsoonal tropical city. Wildl. Res. 1998, 25, 339-356.

9. Franklin, D.C.; Whitehead, P.J.; Pardon, G.; Matthews, J.; McMahon, P.; McIntyre, D. Geographic patterns and correlates of the decline of granivorous birds in northern Australia. Wildl. Res. 2005, 32, 399-408.

10. Crawford, D.N. Birds of Darwin Area, with Some Records from Other Parts of Northern Territory. EMU Austral Ornithol. 1972, 72, 131-148, doi:10.1071/MU972131. 
11. Crawford, D.N. Waterbirds: Indices and fluctuations in dry-season refuge areas, Northern Territory. Aust. Wildl. Res. 1979, 6, 97-103.

12. Lilleyman, A.; Hensen, B.J. The occurrence of the Asian subspecies of the Gull-billed Tern ('Gelochelidon nilotica affinis') in the Darwin region, Northern Territory. North. Territ. Nat. 2014, 25, 12.

13. Lilleyman, A.; Franklin, D.C.; Szabo, J.K.; Lawes, M.J. Behavioural responses of migratory shorebirds to disturbance at a hightide roost. EMU Austral. Ornithol. 2016, 116, 111-118.

14. Noske, R.A. The breeding biology of the mangrove gerygone, Gerygone laevigaster, in the Darwin region, with notes on brood parasitism by the little bronze-cuckoo, Chrysococcyx minutillus. EMU 2001, 101, 129-135.

15. Mohd-Azlan, J.; Noske, R.; Lawes, M. Avian species-assemblage structure and indicator bird species of mangroves in the Australian monsoon tropics. Emu-Austral. Ornithol. 2012, 112, 287-297.

16. Mohd-Azlan, J.; Noske, R.; Lawes, M. The Role of Habitat Heterogeneity in Structuring Mangrove Bird Assemblages. Diversity 2015, 7, 118.

17. Population Division of the United Nations Department of Economic and Social Affairs. 2018 Revision of World Urbanization Prospects; United Nations: 2018.

18. Gaston, K.J. Global patterns in biodiversity. Nature 2000, 405, 220.

19. Emlen, J.T. An urban bird community in Tucson, Arizona: Derivation, structure, regulation. Condor 1974, 76, $184-197$.

20. Chace, J.F.; Walsh, J.J. Urban effects on native avifauna: A review. Landsc. Urban Plan. 2006, 74, 46-69.

21. Conole, L.E.; Kirkpatrick, J.B. Functional and spatial differentiation of urban bird assemblages at the landscape scale. Landsc. Urban Plan. 2011, 100, 11-23, doi:10.1016/j.landurbplan.2010.11.007.

22. Northern Territory Government. Feral Animals. Availabe online: https://nt.gov.au/environment/animals/feral-animals (accessed on 3 October 2018).

23. Australian Bureau of Statistics. 2016 Census QuickStats-Darwin. Availabe online: http://quickstats.censusdata.abs.gov.au/census_services/getproduct/census/2016/quickstat/701? opendocument (accessed on 27 August 2018).

24. Black, D. 1996 Census of Population and Housing: Darwin, a Social Atlas; Statistics, A.B.O., Ed.; Australian Bureau of Statistics: Canberra, ACT, Australia, 1997.

25. Bureau of Meteorology. Climate Statistics for Australian Locations. Availabe online: http://www.bom.gov.au/climate/averages/tables/cw_014015.shtml (accessed on 5 July 2020).

26. Australian Bureau of Statistics. 3218.0-Regional Population Growth, Australia, 2015-16. Availabe online: http://www.abs.gov.au/ausstats/abs@.nsf/PrimaryMainFeatures/3218.0?OpenDocument (accessed on 9 May 2017).

27. Australia, B. birdlife Australia. Availabe online: http://birdlife.org.au (accessed on 19 June 2019).

28. Atlas of Living Australia. Availabe online: https://www.ala.org.au/ (accessed on).

29. Garnett, S.T.; Duursma, D.E.; Ehmke, G.; Guay, P.-J.; Stewart, A.; Szabo, J.K.; Weston, M.A.; Bennett, S.; Crowley, G.M.; Drynan, D.; et al. Australian Bird Data Version 1.0; 2015.

30. Environmental Systems Research Institute (ESRI). ArcGIS 10.4.1 for Desktop; 1999-2015.

31. Conrad, O.; Bechtel, B.; Bock, M.; Dietrich, H.; Fischer, E.; Gerlitz, L.; Wehberg, J.; Wichmann, V.; Böhner, J. System for automated geoscientific analyses (SAGA) v. 2.1.4. Geosci. Model Dev. 2015, 8, 1991-2007.

32. Hahs, A.K.; McDonnell, M.J. Selecting independent measures to quantify Melbourne's urban-rural gradient. Landsc. Urban Plan. 2006, 78, 435-448, doi:10.1016/j.landurbplan.2005.12.005.

33. R Core Team. R: A Language and Environment for Statistical Computing; R Foundation for Statistical Computing: 2019.

34. McCrie, N.; Noske, R. Birds of the Darwin Region; CSIRO PUBLISHING: 2015.

35. Devictor, V.; Julliard, R.; Couvet, D.; Lee, A.; Jiguet, F. Functional homogenization effect of urbanization on bird communities. Conserv. Biol. 2007, 21, 741-751.

36. Öckinger, E.; Schweiger, O.; Crist, T.O.; Debinski, D.M.; Krauss, J.; Kuussaari, M.; Petersen, J.D.; Pöyry, J.; Settele, J.; Summerville, K.S. Life-history traits predict species responses to habitat area and isolation: A cross-continental synthesis. Ecol. Lett. 2010, 13, 969-979.

37. Thomas, C.D. Dispersal and extinction in fragmented landscapes. Proc. R. Soc. Lond. B Biol. Sci. 2000, 267, 139-145.

38. Slade, E.M.; Merckx, T.; Riutta, T.; Bebber, D.P.; Redhead, D.; Riordan, P.; Macdonald, D.W. Life-history traits and landscape characteristics predict macro-moth responses to forest fragmentation. Ecology 2013, 94, 1519-1530.

39. Concepción, E.D.; Moretti, M.; Altermatt, F.; Nobis, M.P.; Obrist, M.K. Impacts of urbanisation on biodiversity: The role of species mobility, degree of specialisation and spatial scale. Oikos 2015, 124, 1571-1582.

40. Parsons, H.; French, K.; Major, R.E. The influence of remnant bushland on the composition of suburban bird assemblages in Australia. Landsc. Urban Plan. 2003, 66, 43-56, doi:10.1016/S0169-2046(03)00094-X.

41. Young, K.M.; Daniels, C.B.; Johnston, G. Species of street tree is important for southern hemisphere bird trophic guilds. Austral Ecol. 2007, 32, 541-550.

42. Major, R.E.; Parsons, H. What do museum specimens tell us about the impact of urbanisation? A comparison of the recent and historical bird communities of Sydney. EMU Austral. Ornithol. 2010, 110, 92-103, doi:10.1071/MU09058.

43. Kark, S.; Iwaniuk, A.; Schalimtzek, A.; Banker, E. Living in the city: Can anyone become an 'urban exploiter'? J. Biogeogr. 2007, 34, 638-651.

44. McKinney, M.L. Urbanization as a major cause of biotic homogenization. Biol. Conserv. 2006, 127, 247-260. 
45. Aronson, M.F.; La Sorte, F.A.; Nilon, C.H.; Katti, M.; Goddard, M.A.; Lepczyk, C.A.; Warren, P.S.; Williams, N.S.; Cilliers, S.; Clarkson, B. A global analysis of the impacts of urbanization on bird and plant diversity reveals key anthropogenic drivers. Proc. R. Soc. B 2014, 281, 20133330. 